\title{
Additional diagnostic value of Diffusion-Weighted Magnetic Resonance Imaging to conventional Magnetic Resonance Imaging in local staging of primary uterine cervical cancer
}

\section{Primer serviks kanserinin lokal evrelemesinde difüzyon ağırlıklı Manyetik Rezonans Görüntülemenin konvansiyonel Manyetik Rezonans Görüntülemeye} katkısı

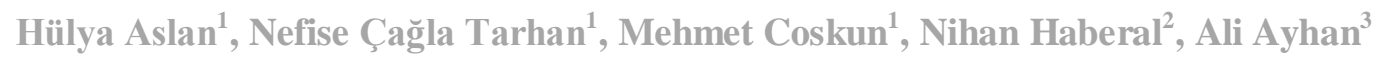

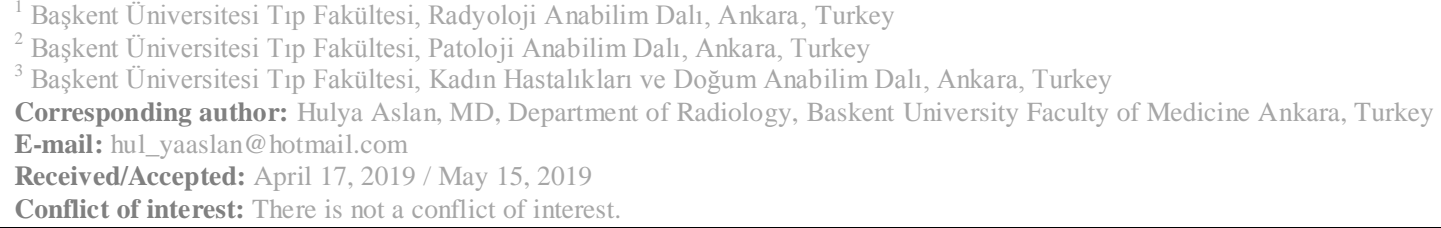

\section{SUMMARY}

Objective: Magnetic resonance (MR) imaging is a helpful modality for detecting and staging gynecological cancers. Diffusion-weighted imaging (DWI) could improve the accuracy rates of MR imaging. The aim of this study was to assess the additional diagnostic value of DWI over conventional MR imaging in assessing the local extent of primary cervical cancer.

Method: Forty patients with primary uterine cervical cancer were enrolled in the study, prospectively. All MR examinations were performed using a 1.5 Tesla Unit MR with a body coil. Sagittal and axial T2-weighted MR images, sagittal and axial DWI (at b values of $0,500,1000 \mathrm{~s} / \mathrm{mm}^{2}$ ) with ADC maps were obtained. The images were evaluated by two different readers independently. The degree of the interobserver agreement between the radiologists was assessed with kappa statistics.

Results: Mean age of the study population was $50.7 \pm 11.1$ years. Kappa values ranged from 0.76 to 1 for both readers, indicating excellent agreement. Accuracy rates were as follows for reader 1 respectively with conventional and conventional plus DWI; stromal invasion 0.92/0.95; parametrial invasion $0.87 / 0.92$; vaginal invasion $0.87 / 0.92$; pelvic sidewall invasion $0.90 / 0.97$. Accuracy rates were as follows for reader 2 respectively with conventional and conventional plus DWI images; stromal invasion 0.90/0.95; parametrial invasion $0.87 / 0.92$; vaginal invasion $0.87 / 0.97$; pelvic sidewall invasion $0.90 / 0.95$.

Conclusions: MR provides satisfactory accuracy rates in the evaluation of the local extent of uterine cervical carcinoma, and adding DWI improves the diagnostic performance of conventional MR.

Keywords: Magnetic Resonance Imaging; diffusion; cervical cancer

\author{
(D) Hülya Aslan \\ (D) Nefise Çağla Tarhan \\ (D) Mehmet Coskun \\ (D)Nihan Haberal \\ (iD) Ali Ayhan
}

ORCID IDs of the authors:

H.A. 0000-0002-7138-246X

N.Ç.T. 0000-0001-9877-7106

M.C. 0000-0003-4481-915X

N.H. 0000-0001-9852-9911

A.A. 0000-0001-7155-9096 
Amaç: Manyetik Rezonans (MR) görüntüleme jinekolojik kanserlerin saptanmasında ve evrelemesinde faydalı bir modalitedir. Difüzyon-ağırlıklı görüntüleme (DAG), MR görüntülemenin tanısal doğruluğunu arttırabilir. Bu çalışmanın amacı primer serviks kanserinin lokal uzanımını değerlendirmede DAG' nin konvansiyonel MR' a katkısını değerlendirmektir.

Yöntem: Primer serviks kanseri tanılı 40 olgu prospektif olarak çalışmaya dahil edildi. Tüm MR incelemeleri 1,5 Tesla MR cihazı ve gövde koili ile yapıldı. Sagital ve aksiyel T2-ağıllıklı MR sekansları, sagital ve aksiyel DAG (b değerleri; $0,500,1000 \mathrm{~s} / \mathrm{mm}^{2}$ ) ile ADC haritaları elde edildi. Görüntüler iki farklı okuyucu tarafından birbirinden bağımsız olarak değerlendirildi. Okuyucular arasındaki uyum kappa testi ile değerlendirildi.

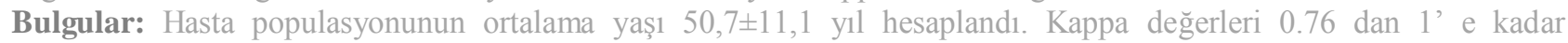
değişmekte olup mükemmel uyum gösterdi. Birinci okuyucu için sırasıyla konvansiyonel MR ve konvansiyonel MR' a DAG eklendiğinde doğruluk oranları şöyleydi; stromal invazyon 0,92/0,95; parametrial invazyon 0,87/0,92; vajinal invazyon 0,87/0,92; pelvik yan duvar invazyonu 0.90/0.97. İkinci okuyucu için sırasıyla konvansiyonel MR ve konvansiyonel MR' a DAG eklendiğinde doğruluk oranları şöyleydi; stromal invazyon 0,90/ 0,95; parametrial invazyon 0,87/0,92; vajinal invazyon 0,87/0,97; pelvik yan duvar invazyonu 0,90/0,95.

Sonuç: MR, serviks kanserinin lokal uzanımını değerlendirmede yeterli doğruluk oranları sağlamakta ve DAG konvansiyonel MR'ın tanısal değerini arttırmaktadır.

Anahtar sözcükler: Manyetik Rezonans Görüntüleme; difüzyon; serviks kanseri

\section{INTRODUCTION}

Uterine cervical cancer is the third most common gynecological malignancy in the world 1 . Although surgery still remains as the most accurate diagnostic approach in staging the disease, pre-surgical imaging of the tumor provides very helpful information, particularly about the local extent of the disease ${ }^{2}$.

The most crucial prognostic factor in cervical cancer staging is the infiltration of the parametrium. Parametrial invasion is also a cutoff criterion for extended surgical approach ${ }^{3,4}$. Patients with parametrial invasion are often treated with primary chemoradiotherapy or may need adjuvant treatment after surgery. Routine parametrectomy is not preferred in the treatment of early-stage cervical cancer because of its association with increased morbidity and mortality 5, 6 . Moreover, the presence of parametrial invasion in uterine cervical cancer associated with disease recurrence and decreased survival rates ${ }^{7,8}$. Therefore, accurate prediction of the parametrial status is essential for appropriate treatment planning and improves patient outcomes.

Magnetic resonance (MR) imaging is an appropriate imaging modality for presurgical staging of cervical cancer with high image resolution 9, 10. Diffusion-weighted magnetic resonance imaging (DWI) is used to evaluate malignant lesions. It provides helpful information about water mobility and tumor cellularity. In the literature, several studies that analyze the additional value of DWI in assessing oncologic staging and therapy response of abdominal tumors have been published.
Herein, we aimed to assess the additional diagnostic value of DWI over T2-weighted MR for detection and assessing deep stromal and parametrial invasion of primary cervical carcinoma.

\section{MATERIAL AND METHODS}

This prospective study was approved by the Institutional Review Board and Ethics Committee and supported by the Baskent University Research Fund (project number: KA11/98). Written informed consent was obtained from each subject before the MR examination.

40 patients who had primary cervical cancer without any treatment prospectively underwent MR examination. Exclusion criteria included contraindications to MR imaging (e.g., cardiac pacemakers), receiving any radiation therapy or chemotherapy. Cervical carcinoma was confirmed in all 40 patients, either by surgery ( 29 patients) or by biopsy (11 patients). 29 patients underwent hysterectomy with or without lymph node dissection. 10 of the patients had advanced cervical carcinoma, and they were directed to radiation therapy with or without chemotherapy. One patient had a low-grade cervical carcinoma, but she couldn't have surgery because of high risk due to cardiac problems.

All patients were staged clinically according to the FIGO staging system at the time of the diagnosis. Other diagnostic tests, including cystoscopy or rectosigmoidoscopy, were performed if needed due to the evaluation of the gynecologic oncologist. FIGO staging was determined after a detailed examination of each patient. 
All MR examinations were performed using a 1.5 $\mathrm{T}$ Unit with a phased-array body coil. MR imaging was performed with sagittal T2-weighted fast spin echo $(7570 \mathrm{msec}$ repetition time; 89 msec echo time, $3 \mathrm{~mm}$ section thickness; $512 \times 512$ acquisition matrix; $250 \mathrm{~mm}$ a field of view; $3: 33$ sec acquisition time, $20 \%$ interslice gap), axial T2-weighted fast spin echo $(7620 \mathrm{msec}$ repetition time; $98 \mathrm{msec}$ echo time, $3 \mathrm{~mm}$ section thickness; 512x512 acquisition matrix; $250 \mathrm{~mm}$ FOV; 3:58 sec acquisition time, 20\% interslice gap).

DWI was performed by sagittal and axial orthogonal planes to the cervix by using singleshot diffusion-weighted echo-planar (102x160 matrix; $27 \mathrm{~cm}$ a field of view; 102 EPI factor, 96, reconstructed to 128; a field of view, $20 \mathrm{~cm}$; and section thickness, $4 \mathrm{~mm}$ ) sequences. b Values of 0,500 , and $1000 \mathrm{sec} / \mathrm{mm}^{2}$ were used.

All MR images were interpreted independently by two radiologists. All MR images were evaluated with respect to the status of the stroma, parametrium, vagina, and pelvic sidewall.

Each reader assigned an overall suspicion score for the probability of the invasion of each parameter on a five-point index scale $(1=$ invasion is definitely absent, 2 = probably absent, $3=$ indeterminate, $4=$ probably present, $5=$ definitely present). In the first session, readers evaluated only sagittal and axial T2 weighted images. One month after the first session, they evaluated each patient with DWI, blinded to their first reading.

\section{Statistical Analysis}

All statistical analysis was performed using statistical software (SPSS, version 15.O; Chicago, IL, USA). The sensitivity, specificity, positive predictive value, negative predictive value, and accuracy rates were calculated. The degree of the interobserver agreement between the two radiologists was assessed with kappa statistics. The reference Kappa values were interpreted as follows: Kappa value less than 0.40 , poor agreement; $0.41-0.75$, moderate to the good agreement; and greater than 0.75, excellent agreement. Values of $p<0.05$ were considered statistically significant.

\section{RESULTS}

The mean age of the study population was $50.7 \pm 11.1$ years.

The histologic subtypes of the patients were; squamous cell carcinoma $(n=36)$ and adenocarcinoma $(n=4)$.

The deep stromal invasion was identified in 33 of the 40 patients (\%82.5) and negative in 7 patients (17.5\%) (Figure1). Adding DWI increased accuracy rates from 0.92 to 0.95 for reader 1 , and from 0.90 to 0.95 for reader 2. Diagnostic performances of both readers in assessing deep stromal invasion were summarized in Table 1.

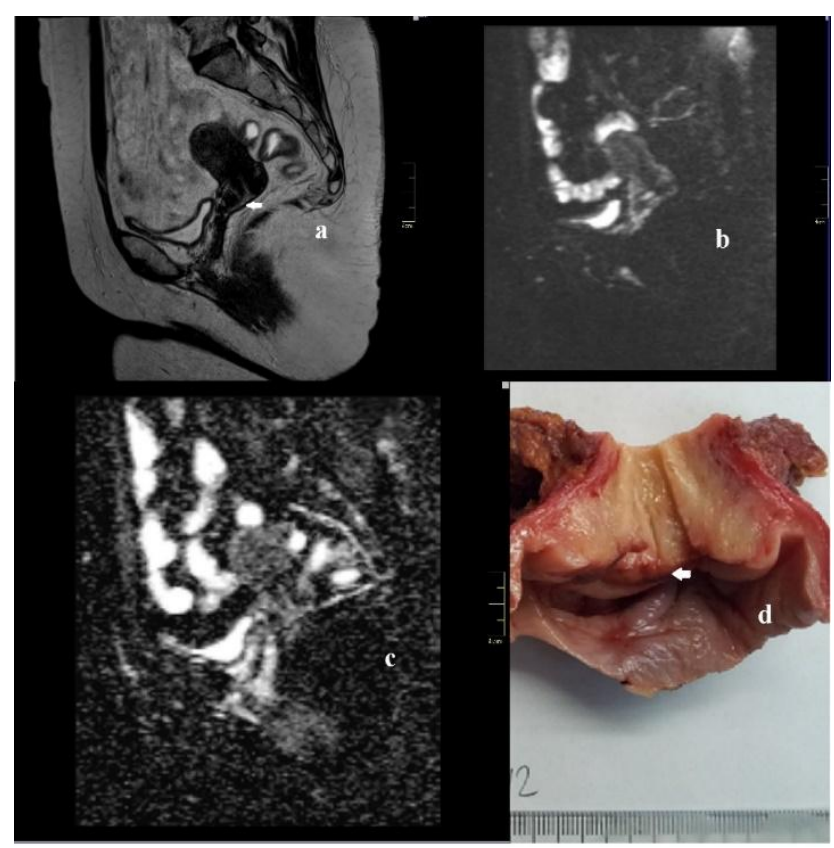

Figure 1a, b, c, d: 31 years-old patient with the cervical tumor. The cervical stroma is intact (white arrows). 
Table 1: Diagnostic performance in assessing deep stromal invasion

\begin{tabular}{|l|c|c|c|c|}
\hline & \multicolumn{1}{|c|}{ Reader 1 } & Reader 1 & Reader 2 & Reader 2 \\
\hline & $\begin{array}{c}\text { T2-weighted } \\
\text { MR }\end{array}$ & $\begin{array}{c}\text { T2-weighted } \\
\text { MR +DWI }\end{array}$ & $\begin{array}{c}\text { T2-weighted } \\
\text { MR }\end{array}$ & $\begin{array}{c}\text { T2-weighted } \\
\text { MR +DWI }\end{array}$ \\
\hline Sensitivity & $0.93(0.79-0.99)$ & $0.96(0.84-0.99)$ & $0.93(0.79-0.99)$ & $0.96(0.84-0.99)$ \\
\hline Specificity & $0.85(0.42-0.99)$ & $0.85(0.42-0.99)$ & $0.71(0.29-0.96)$ & $0.85(0.42-0.99)$ \\
\hline Positive predictive value & $0.96(0.83-0.99)$ & $0.96(0.83-0.99)$ & $0.93(0.82-0.98)$ & $0.96(0.83-0.99)$ \\
\hline Negative predictive value & $0.75(0.43-0.92)$ & $0.85(0.45-0.97)$ & $0.71(0.37-0.91)$ & $0.85(0.45-0.97)$ \\
\hline Accuracy Rate & $0.92(0.79-0.98)$ & $0.95(0.83-0.99)$ & $0.90(0.76-0.97)$ & $0.95(0.83-0.99)$ \\
\hline $\begin{array}{l}\text { Data in parentheses are 95\% Confidence Intervals; MR: Magnetic Resonance Imaging; DWI: Diffusion-weighted } \\
\text { magnetic resonance imaging }\end{array}$
\end{tabular}

The parametrial invasion was positive in the 16 of the 40 patients $(40 \%)$ and negative in 24 patients (60\%) (Figure2). Adding DWI increased accuracy rates from 0.87 to 0.92 for both readers.
Diagnostic performances of both readers in assessing parametrial invasion were summarized in Table 2.
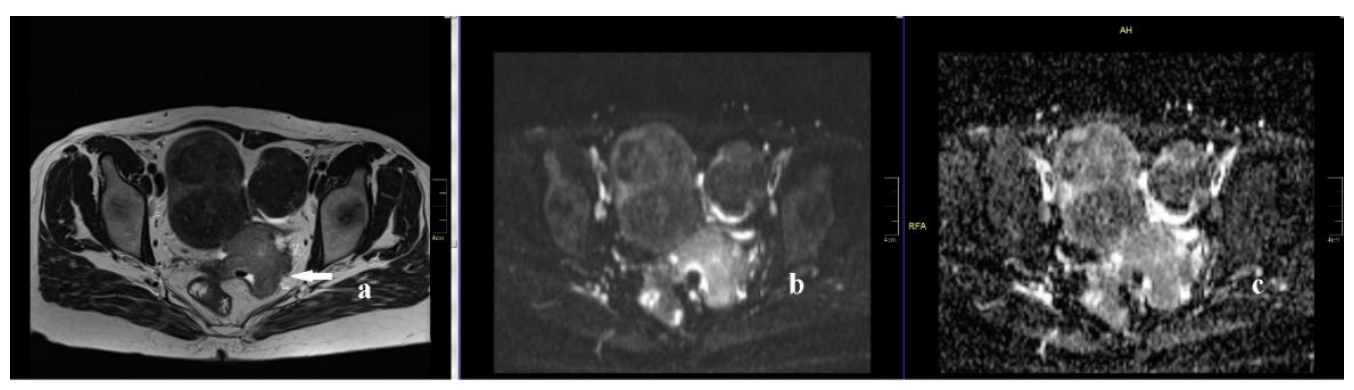

Figure 2a, b, c: 48 years-old patients with the cervical tumor. The parametrium is infiltrated by the tumor (white arrow)

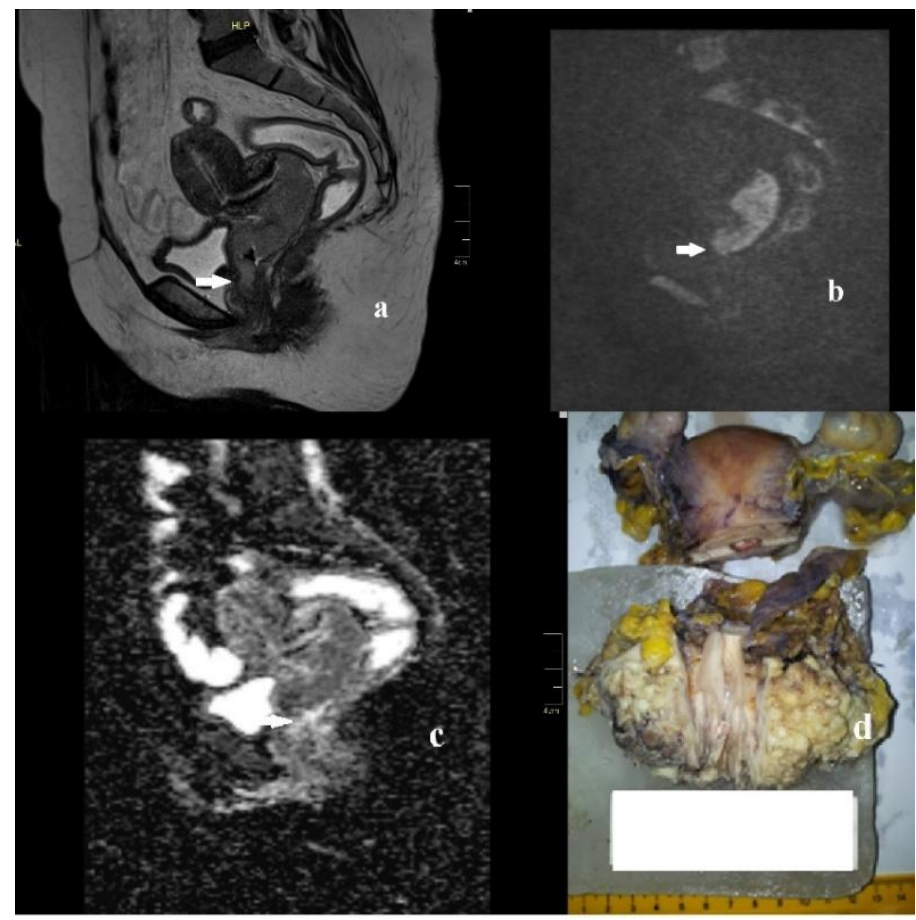

Figure 3 a, b, c, d: 68 years-old patient with the cervical tumor. The tumor is extending to the vagina (white arrows). 
Table 2: Diagnostic performance in assessing parametrial invasion

\begin{tabular}{|l|l|c|c|c|}
\hline & \multicolumn{1}{|c|}{ Reader 1 } & Reader 1 & Reader 2 & Reader 2 \\
\hline & T2-weighted MR & $\begin{array}{c}\text { T2-weighted } \\
\text { MR +DWI }\end{array}$ & $\begin{array}{c}\text { T2-weighted } \\
\text { MR }\end{array}$ & $\begin{array}{c}\text { T2-weighted } \\
\text { MR +DWI }\end{array}$ \\
\hline Sensitivity & $0.81(0.54-0.95)$ & $0.87(0.61-0.98)$ & $0.81(0.54-0.95)$ & $0.87(0.61-0.98)$ \\
\hline Specificity & $0.91(0.73-0.98)$ & $0.95(0.78-0.99)$ & $0.91(0.73-0.98)$ & $0.95(0.78-0.99)$ \\
\hline Positive predictive value & $0.86(0.62-0.96)$ & $0.93(0.67-0.98)$ & $0.86(0.62-0.96)$ & $0.93(0.67-0.98)$ \\
\hline Negative predictive value & $0.88(0.72-0.95)$ & $0.92(0.75-0.97)$ & $0.88(0.72-0.95)$ & $0.92(0.75-0.97)$ \\
\hline Accuracy Rate & $0.87(0.73-0.95)$ & $0.92(0.79-0.98)$ & $0.87(0.73-0.95)$ & $0.92(0.79-0.98)$ \\
\hline
\end{tabular}

Data in parentheses are 95\% Confidence Intervals; MR: Magnetic Resonance Imaging; DWI: Diffusion-weighted magnetic resonance imaging

The vaginal invasion was positive in only 6 patients (15\%) (Figure3). Adding DWI increased accuracy rates from 0.87 to 0.92 for reader 1 , and from 0.87 to 0.97 for reader 2. Diagnostic performances of both readers in assessing vaginal invasion were summarized in Table 3.

Table 3: Diagnostic performance in assessing vaginal invasion

\begin{tabular}{|l|c|c|c|c|}
\hline & Reader 1 & Reader 1 & Reader 2 & \multicolumn{1}{c|}{ Reader 2 } \\
\hline & $\begin{array}{c}\text { T2-weighted } \\
\text { MR }\end{array}$ & $\begin{array}{c}\text { T2-weighted } \\
\text { MR +DWI }\end{array}$ & $\begin{array}{c}\text { T2-weighted } \\
\text { MR }\end{array}$ & $\begin{array}{c}\text { T2-weighted } \\
\text { MR +DWI }\end{array}$ \\
\hline Sensitivity & $0.81(0.54-0.95)$ & $0.87(0.61,0.98)$ & $0.66(0.22-0.95)$ & $1(0.54-1)$ \\
\hline Specificity & $0.91(0.73-0.98)$ & $0.95(0.78,0.99)$ & $0.91(0.76-0.98)$ & $0.97(0.84-0.99)$ \\
\hline Positive predictive value & $0.86(0.62-0.96)$ & $0.93(0.67,0.98)$ & $0.57(0.28-0.81)$ & $0.85(0.46-0.97)$ \\
\hline Negative predictive value & $0.88(0.72-0.95)$ & $0.92(0.75,0.97)$ & $0.93(0.83-0.97)$ & 1 \\
\hline Accuracy Rate & $0.87(0.73-0.95)$ & $0.92(0.79,0.98)$ & $0.87(0.73-0.95)$ & $0.97(0.86-0.99)$ \\
\hline
\end{tabular}

Data in parentheses are 95\% Confidence Intervals; MR: Magnetic Resonance Imaging; DWI: Diffusion-weighted magnetic resonance imaging

The pelvic sidewall invasion was positive in only 3 patients (7.5\%) (Figure4). Adding DWI increased accuracy rates from 0.90 to 0.97 for reader 1 , and from 0.90 to 0.95 for reader 2 .
Diagnostic performances of both readers in the pelvic sidewall invasion were summarized in Table 4.

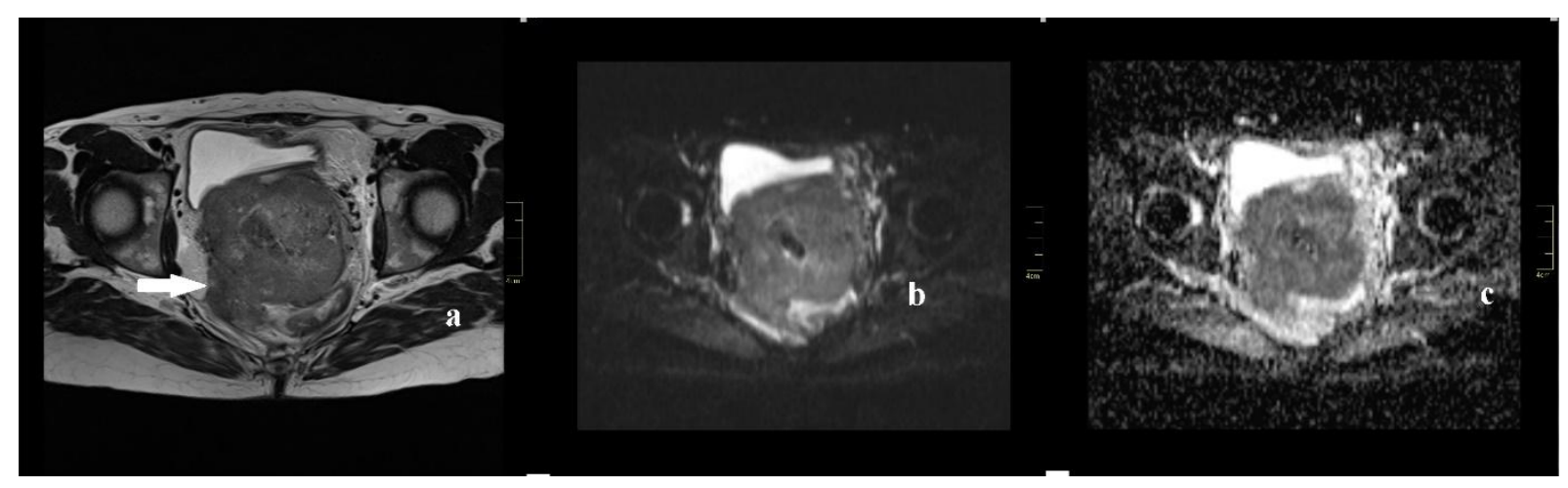

Figure 4 a, b, c: 68 years-old patient with the cervical tumor. The tumor is extending to the pelvic sidewall (white arrow). 
Table 4: Diagnostic performance in assessing pelvic sidewall invasion

\begin{tabular}{|l|l|l|l|l|}
\hline & \multicolumn{1}{|c|}{ Reader 1 } & \multicolumn{1}{c|}{ Reader 1 } & \multicolumn{1}{c|}{ Reader 2 } & \multicolumn{1}{c|}{ Reader 2 } \\
\hline & T2-weighted MR & $\begin{array}{c}\text { T2-weighted } \\
\text { MR +DWI }\end{array}$ & $\begin{array}{c}\text { T2-weighted } \\
\text { MR }\end{array}$ & $\begin{array}{c}\text { T2-weighted } \\
\text { MR +DWI }\end{array}$ \\
\hline Sensitivity & $0.66(0.94-0.99)$ & $1(0.29-1)$ & $0.66(0.94-0.99)$ & $1(0.29-1)$ \\
\hline Specificity & $0.91(0.78-0.98)$ & $0.97(0.85-0.99)$ & $0.91(0.78-0.98)$ & $0.94(0.81-0.99)$ \\
\hline Positive predictive value & $0.40(0.14-0.71)$ & $0.75(0.30-0.95)$ & $0.40(0.14-0.71)$ & $0.60(0.28-0.85)$ \\
\hline Negative predictive value & $0.97(0.87-0.99)$ & 1 & $0.97(0.87-0.99)$ & 1 \\
\hline Accuracy Rate & $0.90(0.76-0.97)$ & $0.97(0.86-0.99)$ & $0.90(0.76-0.97)$ & $0.95(0.83-0.99)$ \\
\hline
\end{tabular}

Data in parentheses are 95\% Confidence Intervals; MR: Magnetic Resonance Imaging; DWI: Diffusionweighted magnetic resonance imaging

Kappa values ranged from 0.76 to 1 for both readers, indicating excellent agreement.

\section{DISCUSSION}

In the present study, we searched the additional diagnostic value of DWI in assessing the local extent of uterine cervical cancer. Adding DWI improved accuracy rates for both readers in assessing the extent of disease to the stroma, parametrium, vagina, and pelvic sidewall.

The parametrial status is one of the most important factors in planning the treatment of uterine cervical cancer. Previously in the literature, MR showed high accuracy rates from $\% 80$ to $94 \%$ for assessing parametrial invasion with conventional MR sequences ${ }^{11-13}$. Only T2weighted imaging has been reported to reach approximately $75 \%$ sensitivity and $70 \%$ specificity in the accurate evaluation of parametrial status ${ }^{14}$. Our results correlate well with these results. Moreover, T2-weighted imaging has been suggested as the clinical standard for preoperative assessment of cervical carcinoma because of its high soft tissue resolution in showing the zonal anatomy of the uterus ${ }^{15}$. Previously, Qu et al. showed that adding DWI enhanced the accuracy of detecting parametrial invasion with 3 Tesla MR ${ }^{16}$. Although we used a 1.5 Tesla MR Unit, the accuracy rates increased from 0.87 to 0.92 after adding DWI to conventional MR for both readers. The fusion of T2-weighted imaging and DWI is a relatively new post-processed imaging tool, and it gives both anatomical and functional information about the tumor. Previously, Park et al. showed that the fusion of DWI with T2-weighted imaging improved the diagnostic performance of MR compared with $\mathrm{T} 2$-weighted imaging alone in detecting parametrial invasion ${ }^{17}$. This technology could be suggested for further studies.
The stromal status could be important for the patient selection for radical trachelectomy ${ }^{18-22}$. While evaluating T2-weighted images, cervical stroma was considered normal if it demonstrated homogeneous low signal intensity. The cervical stromal invasion was considered positive if the normal low signal intensity stroma was disrupted by the tumor. Previously, Lakhman et al. reported sensitivity rates from 0.50 to 075 and specificity rates from 0.90 to 0.94 in detecting deep stromal invasion for different readers with contrastenhanced MR studies among patients with stages IB1, IB2, and IIA ${ }^{18}$. We showed sensitivity rates from 0.93 to 0.96 and specificity rates from 0.71 to 0.85 in our study. MR showed high sensitivity and specificity rates for assessing deep stromal invasion.

The presence of vaginal invasion is determined when the low signal intensity of the vaginal wall was disrupted by a high-intensity tumor. In the literature, previously reported studies showed accuracy rates with a range of $81 \%-100 \%$ for vaginal evaluation with contrast-enhanced studies 13, 23. There are limited numbers of studies in the literature with DWI. In our study, DWI improved the accuracy rates for both readers in assessing vaginal invasion.

Accurate staging of the pelvic sidewall is also important, and MR provides excellent images of the pelvic floor anatomy. Pelvic sidewall involvement (stage IIIB) is diagnosed when a tumor is seen within $3 \mathrm{~mm}$ from the internal obturator, levator ani or pyriformis muscles; encasement of the iliac vessels is also diagnostic for pelvic sidewall invasion ${ }^{24}$. The presence of hydronephrosis/hydroureter should also be investigated. Our study showed promising and reliable results in assessing the status of the pelvic sidewall with DWI. 
There are several limitations to this study. The small sample size is one of our limitations. Further studies with large sample sizes are needed to support our results. One of our limitations was the patients who did not have surgery, so they were staged only clinically based on the FIGO staging. Actually, these patients underwent a detailed clinical examination, including cystoscopy or rectosigmoidoscopy if needed. On the other hand, the strength of this study was assessing interobserver agreement and the prospective design of the study. In this study, both conventional MR images and DWI showed high interobserver agreement rates, and this may increase the clinical application of DWI.

In conclusion, MR provides satisfactory accuracy rates in the evaluation of the local extent of uterine cervical carcinoma; and adding DWI improves the diagnostic performance of conventional MR.

\section{REFERENCES}

1. Ho"ckel M, Horn LC, Einenkel J. Laterally extended endopelvic resection: surgical treatment of locally advanced and recurrent cancer of the uterine cervix and vagina based on ontogenetic anatomy. Gynecol Oncol. 2012;127:297-302.

2. Narayan K, Lin MY. Staging for cervix cancer: Role of radiology, surgery, and clinical assessment.Best Pract Res Clin Obstet Gynaecol.2015;29:833-844.

3. Ho“ckel M, Horn LC, Hentschel B, et al. Total mesometrial resection: high resolution nervesparing radical hysterectomy based on developmentally defined surgical anatomy. Int $\mathbf{J}$ Gynecol Cancer. 2003;13:791-803.

4. Mangler M, Zech N, Schneider A, et al. Aspects of therapy for cervical cancer in Germany 2012: Results from a survey of German gynecological hospitals. Geburtshilfe Frauenheilkd. 2013;73:227-238.

5. Zullo MA, Manci N, Angioli R, et al. Vesical dysfunctions after radical hysterectomy for cervical cancer: a critical review. Crit Rev Oncol Hematol. 2003;48:287-293.

6. Raspagliesi F, Ditto A, Fontanelli R, et al. Type II versus Type III nerve-sparing radical hysterectomy: comparison of lower urinary tract dysfunctions. Gynecol Oncol. 2006;102:256-262.

7. Delgado G, Bundy BN, Fowler WC Jr, et al. A prospective surgical pathological study of stage I squamous carcinoma of the cervix: a Gynecologic
Oncology Group Study. Gynecol Oncol. 1989;35: 314-320.

8. Landoni F, Bocciolone L, Perego P, et al. Cancer of the cervix, FIGO stages IB and IIA: patterns of local growth and paracervical extension. Int J Gynecol Cancer.1995;5:329-334.

9. Balleyguier C, Sala E, Da Cunha T, et al. Staging of uterine cervical cancer with MRI: guidelines of the European Society of Urogenital Radiology. Eur Radiol. 2011;21:1102-1110.

10. Bhosale P, Peungjesada S, Devine C, et al. Role of magnetic resonance imaging as an adjunct to clinical staging in cervical carcinoma. J Comput Assist Tomogr. 2010;34:855-864.

11. Janus CL, Mendelson DS, Moore S, et al. Staging of cervical carcinoma; the accuracy of magnetic resonance imaging and computed tomography. Clin Imaging. 1989;13:114-116.

12. Subak LL, Hricak H, Powell CB, et al. Cervical carcinoma: computed tomography and magnetic resonance imaging for preoperative staging. Obstet Gynecol. 1995;86:43-50.

13. Sheu MH, Chang CY, Wang JH, Yen MS. Preoperative staging of cervical carcinoma with MR imaging: a reappraisal of diagnostic accuracy and pitfalls. Eur Radiol. 2001;11:1828-1833.

14. Hori M, Kim T, Murakami T, et al. Uterine cervical carcinoma: preoperative staging with 3.0$\mathrm{T}$ MR imaging - comparison with 1.5-T MR imaging. Radiology.2009; 251:96-104.

15. Thomeer MG, Gerestein C, Spronk S, et al. Clinical examination versus magnetic resonance imaging in the pretreatment staging of cervical carcinoma: systematic review and meta-analysis. Eur Radiol.2013; 23:2005-2201.

16. Qu JR, Qin L, Li X,et al. Predicting Parametrial Invasion in Cervical Carcinoma (Stages IB1, IB2, and IIA): Diagnostic Accuracy of T2-Weighted Imaging Combined With DWI at 3 T. AJR Am J Roentgenol.2018;210:677-684.

17. Park JJ, Kim CK, Park SY, Park BK. Parametrial invasion in cervical cancer: fused T2weighted imaging and high-b-value diffusionweighted imaging with background body signal suppression at 3 T. Radiology 2015;274:734-741.

18. Lakhman Y, Akin O, Park KJ, et al. Stage IB1 cervical cancer: role of preoperative MR imaging in selection of patients for fertility-sparing radical trachelectomy. Radiology. 2013;269:149-158. 
19. Rob L, Skapa P, Robova H. Fertility-sparing surgery in patients with cervical cancer. Lancet Oncol. 2011;12:192-200.

20. Abu-Rustum NR, Sonoda Y. Fertility-sparing surgery in early-stage cervical cancer: indications and applications. J Natl Compr Canc Netw. 2010;8:1435-1438.

21. Dursun P, LeBlanc E, Nogueira MC. Radical vaginal trachelectomy (Dargent's operation): a critical review of the literature. Eur J Surg Oncol. 2007;33:933-941.
22. Covens A. Preserving fertility in early cervical cancer with radical trachelectomy. Contemp Obstet Gynecol. 2003;2:46-66.

23. Boss EA, Barentsz JO, Massuger LF, et al. The role of MR imaging in invasive cervical carcinoma. Eur Radiol. 2000;10:256-270.

24. Bourgioti C, Chatoupis K, Moulopoulos LA. Current imaging strategies for the evaluation of uterine cervical cancer. World J Radiol. 2016;28:342-354. 